\title{
RESEARCH
}

Open Access

\section{Testing a MultiTEP-based combination vaccine to reduce $A \beta$ and tau pathology in Tau22/5xFAD bigenic mice}

Hayk Davtyan 1,2,3* D, Armine Hovakimyan', Sepideh Kiani Shabestari ${ }^{3}$, Tatevik Antonyan ${ }^{1}$, Morgan A. Coburn ${ }^{3,4}$, Karen Zagorski 1,5, Gor Chailyan', Irina Petrushina², Olga Svystun', Emma Danhash ${ }^{2,3,6}$, Nikolai Petrovsky, David H. Cribbs², Michael G. Agadjanyan ${ }^{1}$, Mathew Blurton-Jones ${ }^{2,3,4,6+}$ and Anahit Ghochikyan ${ }^{1+}$

\begin{abstract}
Background: Alzheimer disease (AD) is characterized by the accumulation of beta-amyloid (A $\beta$ ) plaques and neurofibrillary tangles composed of hyperphosphorylated tau, which together lead to neurodegeneration and cognitive decline. Current therapeutic approaches have primarily aimed to reduce pathological aggregates of either $A \beta$ or tau, yet phase 3 clinical trials of these approaches have thus far failed to delay disease progression in humans. Strong preclinical evidence indicates that these two abnormally aggregated proteins interact synergistically to drive downstream neurodegeneration. Therefore, combinatorial therapies that concurrently target both $A \beta$ and tau might be needed for effective disease modification.

Methods: A combinatorial vaccination approach was designed to concurrently target both $A \beta$ and tau pathologies. Tau22/5xFAD (T5x) bigenic mice that develop both pathological A $\beta$ and tau aggregates were injected intramuscularly with a mixture of two MultiTEP epitope vaccines: AV-1959R and AV-1980R, targeting A $\beta$ and tau, respectively, and formulated in $\mathrm{Advax}{ }^{\mathrm{CpG}}$, a potent polysaccharide adjuvant. Antibody responses of vaccinated animals were measured by ELISA, and neuropathological changes were determined in brain homogenates of vaccinated and control mice using ELISA and Meso Scale Discovery (MSD) multiplex assays.

Results: T5x mice immunized with a mixture of $A \beta$ - and tau-targeting vaccines generated high $A \beta$ - and tau-specific antibody titers that recognized senile plaques and neurofibrillary tangles/neuropil threads in human AD brain sections. Production of these antibodies in turn led to significant reductions in the levels of soluble and insoluble total tau, and hyperphosphorylated tau as well as insoluble $A \beta_{42}$, within the brains of bigenic $T 5 x$ mice.

Conclusions: AV-1959R and AV-1980R formulated with $A d v a x^{C P G}$ adjuvant are immunogenic and therapeutically potent vaccines that in combination can effectively reduce both of the hallmark pathologies of AD in bigenic mice. Taken together, these findings warrant further development of this vaccine technology for ultimate testing in human AD.
\end{abstract}

Keywords: MultiTEP platform, Alzheimer's disease, Protein epitope vaccine, Antibody, Adjuvant, Bigenic mice, T5x mice, $A \beta_{42}$ and tau pathology

\footnotetext{
*Correspondence: hdavtyan@uci.edu

${ }^{\dagger}$ Mathew Blurton-Jones and Anahit Ghochikyan contributed equally to this work.

'Department of Molecular Immunology, Institute for Molecular Medicine, Huntington Beach, CA, USA

${ }^{2}$ Institute for Memory Impairments and Neurological Disorders, University of California, Irvine, Irvine, CA, USA

Full list of author information is available at the end of the article
}

(c) The Author(s). 2019 Open Access This article is distributed under the terms of the Creative Commons Attribution 4.0 International License (http://creativecommons.org/licenses/by/4.0/), which permits unrestricted use, distribution, and reproduction in any medium, provided you give appropriate credit to the original author(s) and the source, provide a link to the Creative Commons license, and indicate if changes were made. The Creative Commons Public Domain Dedication waiver (http://creativecommons.org/publicdomain/zero/1.0/) applies to the data made available in this article, unless otherwise stated. 


\section{Background}

Alzheimer's disease (AD) is a complex and multifactorial disease involving genetic and environmental risk factors that together lead to the progressive accumulation of two hallmark pathologies: $\beta$-amyloid plaques and neurofibrillary tangles (NFTs). Although many clinical trials have aimed to reduce $\beta$-amyloid and, more recently, to target the accumulation of tau that drives NFT formation, debate remains regarding which of these pathologies represents the most tractable target, and the precise timing for these potential treatments. Recent longitudinal analyses of participants within the Alzheimer's Disease Neuroimaging Initiative (ADNI) demonstrated evidence of synergism between $A \beta$ and phosphorylated tau (p-tau) suggesting these pathologies may interact to trigger the progression from amnestic mild cognitive impairment $(\mathrm{MCI})$ subjects to AD dementia $[1,2]$. PET imaging studies suggest that $\mathrm{A} \beta$ deposits start decades before dementia onset, and may or may not precede tau pathology, with the latter correlating better with symptom onset and the degree of dementia [3, 4]. According to the modified amyloid cascade model proposed by Jack et al. [5-7], primary age-related tauopathy (PART) develops universally as a function of aging and, by itself, produces no or only mild cognitive symptoms. $A \beta$ deposition occurs independently in the neocortex and induces or facilitates the spread of pathological tau, perhaps by promoting the production of pathological tau strains [8]. Pathological tau is directly associated with neurodegeneration, which in turn drives cognitive decline. In this model of $\mathrm{AD}, \mathrm{A} \beta$ does not directly cause cognitive symptoms but is still central to disease pathogenesis as a dominant driver of downstream pathological processes including tau pathology $[6,7]$. Indeed, a recent study utilizing serial PET measurements of both amyloid and tau provides strong additional support for this hypothesis [9].

This synergistic model suggests that combinatorial/ multi-target therapies directed at the accumulation of both amyloid and tau pathologies may be more effective in the treatment of $\mathrm{AD}$ than previously tested unimodal approaches.

Recently, we demonstrated that the combination of $A V-1959 R$ and AV-1980R vaccines targeting $A \beta$ and tau, respectively, induced robust antibody responses against various forms of both $A \beta$ and tau pathological molecules in wildtype mice [10]. Both of these vaccines are based on the MultiTEP platform that consists of a string of 12 non-self, pathogen-derived $\mathrm{T}$ helper (Th) epitopes to which A $\beta$ B cell epitopes (AV-1959R) and tau B cell epitopes (AV-1980R) are attached. A dual vaccine expressing both $A \beta$ and tau $B$ cell epitopes (AV-1953R) generated similar concentrations of anti-A $\beta$ antibodies, but significantly lower concentrations of anti-tau antibodies compared to mice vaccinated with a combination of AV-1959R and AV-1980R [10], suggesting a mixed vaccine approach may be preferred.

Here, we tested the therapeutic efficacy of coformulated vaccines targeting $A \beta$ and tau administered simultaneously in combination with Advax ${ }^{\mathrm{CpG}}$ adjuvant in the Tau22/5xFAD (T5x) mouse model of AD. T5x bigenic mice [11] were generated by crossing two existing and well-characterized transgenic models, 5xFAD [12] and THY-Tau22 [13], and were previously shown to develop highly aggressive $A \beta$ and tau pathology, and thus likely represent a useful model for testing potential AD therapies. The bigenic T5x mice exhibit an approximately threefold increase in misfolded and hyperphosphorylated tau over the parental Tau22 strain, further supporting the hypothesis that $A \beta$ accelerates tau pathology [11].

\section{Materials and methods Mice}

Thy-Tau22-5xFAD (T5x) double transgenic AD mice were generated as described in [11]. Briefly, Thy-Tau22 mice express human 4 repeat tau with two frontotemporal dementia-associated point mutations (G272V and P301S) under control of the neuronal driven promoter Thy1.2 and are maintained on a C57Bl6/J background [13]. The 5xFAD mice used in this study are also maintained on a congenic C57Bl6/J and co-expresses human amyloid precursor protein (APP695) carrying the Swedish, Florida, and London mutations and a human presenilin-1 (PS1) transgene carrying the M146L and L286V mutations under the Thy-1 promoter. Both APP and PS1 transgenes are co-integrated and thus coinherited. Heterozygous Thy-Tau22 and 5xFAD mice were crossed to create Thy-Tau22-5xFAD (T5x) mice that were genotyped via PCR amplification of human tau, PS1, and APP transgenes. Both female and male animals were used in this study and sex-dependent effects examined. All animals were housed in a temperature and light cycle-controlled facility, and their care was under the guidelines of the National Institutes of Health and an approved IACUC protocol at University of California, Irvine.

\section{Epitope vaccines and purification of proteins}

To prepare two recombinant proteins, minigenes encoding $3 \mathrm{~A} \beta_{1-11}$-MultiTEP or $3 \mathrm{Tau}_{2-18}$-MultiTEP were cloned into the modified Escherichia coli expression vector pET11 (for AV-1959R; Novagen, MA) or pET24a (for AV-1980R; Novagen, MA) in frame with 6xHis-Tag at the C-terminus. Gene encoding $2 \mathrm{~N} 4 \mathrm{R}$ tau protein was amplified from human whole brain Marathon ${ }^{\oplus}$-Ready cDNA library (Clontech) using primers 5'-catatggctgagcccogcaggagttcgaagtgatg (forward) and $5^{\prime}$ - 
ctcgagtcacaaaccctgcttggccagggaggcagac (reverse) and cloned into the pET24a $+E$. coli expression vector in frame with $6 \mathrm{xHis}$-tag at the $\mathrm{C}$-terminus using restriction sites NdeI and XhoI. DNA sequencing was performed to confirm that the generated plasmids contained the correct sequences. Recombinant proteins were purified from $E$. coli BL21 (DE3) cells transformed with pET11/ $3 \mathrm{~A} \beta_{1-11}$-MultiTEP, $\quad$ pET24a/3Tau $2-18$-MultiTEP, or pET24a/Tau plasmids as described $[10,14,15]$ for epitope vaccines and in [16] for Tau protein. The final recombinant protein was analyzed in $10 \%$ Bis-Tris gel electrophoresis (NuPAGE Novex Gel, Invitrogen, CA). Protein bands were visualized by Coomassie dye, and specificity of the bands was confirmed by Western blot (WB) using 6E10 and anti-tau $2-18$ 1C9 monoclonal antibodies [10]. The level of endotoxin was measured using E-TOXATE kits, as recommended by the manufacturer (Sigma, St Louis, MO).

\section{Preparation of oligomeric recombinant tau}

Oligomeric forms of tau protein were prepared as described by Combs et al. [17]. Briefly, arachidonic acid in ethanol was added to recombinant tau protein in polymerization buffer $(5 \mathrm{mM}$ DTT, $100 \mathrm{mM} \mathrm{NaCl}$, $100 \mu \mathrm{M}$ EDTA, and $10 \mathrm{mM}$ HEPES at $\mathrm{pH} 7.64$ ) to a final concentration of $75 \mu \mathrm{M}$ in order to induce tau polymerization. The reaction was allowed to proceed overnight, and the extent of aggregation was confirmed by western blotting. The aggregated tau sample was aliquoted and was stored at $-80^{\circ} \mathrm{C}$ until used in SPR assay.

\section{Experimental protocols}

Three groups of T5x mice were immunized with AV-1959R (20 $\mu \mathrm{g} /$ per mouse/per injection), AV-1980R $(20 \mu \mathrm{g} / \mathrm{per}$ mouse/per injection), or a mixture of AV-1959R and AV1980R proteins (20 $\mu \mathrm{g}$ protein/mouse/injection), all formulated with Advax ${ }^{\mathrm{CpG}}$ adjuvant (Vaxine Pty Ltd., Adelaide Australia) at $1 \mathrm{mg} / \mathrm{mouse} /$ injection. Control groups of $\mathrm{T} 5 \mathrm{x}$ mice were injected with Advax ${ }^{\mathrm{CpG}}$ adjuvant only or PBS. All mice were injected four times intramuscularly. Sera were collected 14 days after third immunizations, and anti-A $\beta$ and anti-tau antibody responses were analyzed. At age of 8 months old, mice were terminated and brains were collected for biochemical and immunohistological analysis. More detailed experimental protocols are provided in Fig. 1.

\section{Detection of $A \beta$ - and tau-specific antibodies}

The concentrations of anti- $\mathrm{A} \beta$ and anti-tau antibodies in serum were determined by ELISA, as described previously $[15,18,19]$. To measure anti- $\mathrm{A} \beta$ and anti-tau antibody concentration, plates were coated with $1 \mu \mathrm{g} / \mathrm{per}$ well $\mathrm{A} \beta_{42}$ peptide (American Peptide, CA), tau ${ }_{2-18}$ peptide (GenScript, NJ), or full-length recombinant tau protein (purified at The Institute for Molecular Medicine, Huntington Beach, CA), respectively. Anti-A $\beta$ and antitau antibody concentrations were calculated using a calibration curve generated with affinity-purified polyclonal

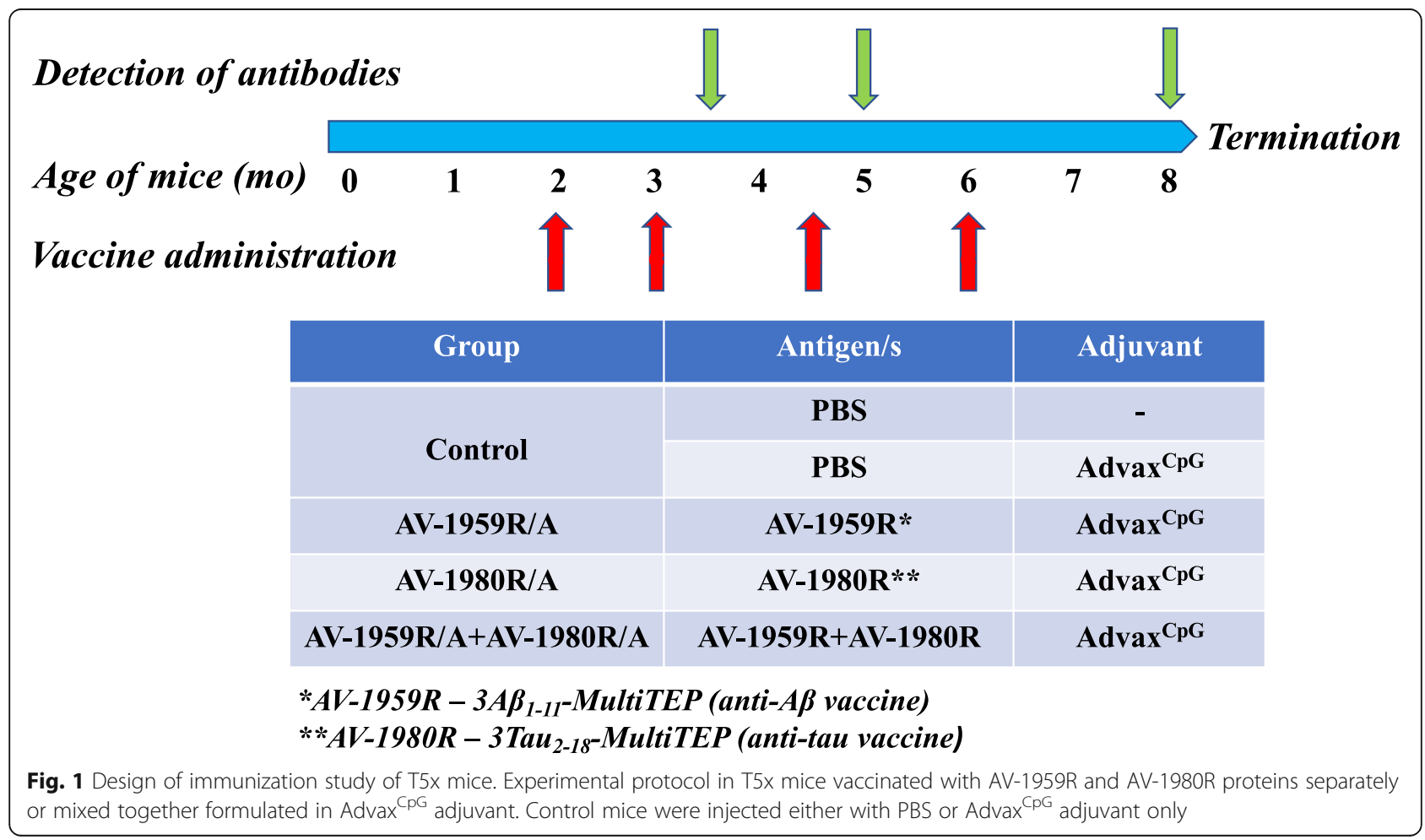


antibodies from sera of mice vaccinated with AV-1959R/ A and AV-1980R/A, respectively. HRP-conjugated antimouse IgG (Jackson ImmunoResearch Laboratories, ME) was used as secondary antibody.

\section{Epitope mapping of tau-specific antibodies}

Epitope mapping of anti-tau antibodies was performed by "alanine scanning" using competitive ELISA. Briefly, 17 peptides spanning tau tis $_{2-18}$ sequence, but possessing one alanine substitution in each position were synthesized. Ninety-six-well plates (Immulux HB; Dynex Technologies, Inc., VA) were coated with $1 \mu \mathrm{g} /$ well (in $100 \mu \mathrm{l}$; Carbonate-Bicarbonate buffer, $\mathrm{pH} 9.6, \mathrm{o} / \mathrm{n}$ at $4{ }^{\circ} \mathrm{C}$ ) tau $\mathrm{ta}_{2}$ 18 peptide (GenScript, NJ). Next day coated plates were blocked with blocking buffer (3\% dry, non-fat milk in TBST, $300 \mu \mathrm{l} /$ well). Serial dilutions of reference wild type $\left(\operatorname{tau}_{2-18}\right)$ or mutated test peptides (corresponding to $0.02 \mu \mathrm{M}, 0.1 \mu \mathrm{M}, 0.5 \mu \mathrm{M}, 2.5 \mu \mathrm{M}, 5 \mu \mathrm{M}, 12.5 \mu \mathrm{M}$, and $25 \mu \mathrm{M}$ final concentrations) were incubated with immune sera diluted 1: 300,000 (corresponding to the linear region of the curve for binding to $\mathrm{Tau}_{2-18}$ peptide) for $1.5 \mathrm{~h}$ at $37^{\circ} \mathrm{C}$. After incubation, $100 \mu \mathrm{l}$ of antibody/ peptide mixture was added into the wells. HRPconjugated goat anti-mouse IgG (1:2500; Jackson ImmunoResearch Laboratories, PA) were used as secondary antibodies. The reaction was developed by adding 3,3',5, 5 'tetramethylbenzidine (TMB) (Pierce, IL) substrate solution and stopped with $2 \mathrm{M} \mathrm{H}_{2} \mathrm{SO}_{4}$. The optical density (OD) was read at $450 \mathrm{~nm}$ (Biotek, Synergy HT, VT). The percent of binding of sera blocked with wild type or mutated peptides to $\operatorname{tau}_{2-18}$ was calculated relative to the binding of sera without competing peptides to $\operatorname{tau}_{2-18}$ as $100 \%$. The half maximal inhibitory concentration $\left(\mathrm{IC}_{50}\right)$ for each peptide was calculated.

\section{Surface plasmon resonance (SPR)}

Binding studies were performed at $25^{\circ} \mathrm{C}$ using a Biacore 2000 optical biosensor equipped with a Protein A-coated sensor chip and equilibrated with running buffer (10 $\mathrm{mM}$ HEPES, $150 \mathrm{mM} \mathrm{NaCl}, 0.01 \%$ Tween-20, $0.1 \mathrm{mg} /$ $\mathrm{mL}$ BSA, $\mathrm{pH}$ 7.4). The surfaces were regenerated with two 12-s injections of $150 \mathrm{mM}$ phosphoric acid after each binding cycle.

Antibody captures for kinetic analysis of antigen binding. For each binding cycle, the antibodies were diluted into running buffer and injected across individual Protein A surfaces. These injections produced capture levels of 55-75 RU (resonance units). Using a short-andlong injection approach, tau monomer and oligomer were tested in triplicate in a threefold dilution series starting at $40 \mathrm{nM}$ (this concentration was established using an estimated average molecular weight of $138 \mathrm{kDa}$ for the oligomer). For each tau/antibody interaction, the responses from the three runs were globally fitted to a 1 :
1 interaction model (shown as the overlaid smooth red lines in the figures) to obtain the binding parameters listed in the table in Fig. 4.

\section{Detection of $A \beta$ plaques and tau tangles in human brain tissues by IHC and confocal microscopy}

Sera from mice immunized with AV-1959R/A, AV1980R/A, and mixture of AV-1959R/A and AV-1980R/ $A$, as well as control mice injected with Advax ${ }^{\mathrm{CpG}}$ only, were screened for the ability to bind to human $A \beta$ plaques or/and tau tangles using $40-\mu \mathrm{m}$ brain sections of formalin-fixed cortical tissues from a severe AD case (received from Brain Bank and Tissue Repository, MIND, UC Irvine) using immunohistochemistry, as described previously [20-22]. In addition, brain sections were stained with anti-A $\beta$ (beta-amyloid (1-42), 1:250, Invitrogen, CA) and humanized anti-tau (Armanezumab, 1: 1000; Institute for Molecular Medicine, CA) antibody as positive controls. Sections were imaged using an Olympus FX1200 confocal microscope, with identical laser and detection settings across a given immunolabel.

\section{Mouse brain tissue preparation, immunohistochemistry, and confocal microscopy}

Following perfusion, one hemisphere from each mouse was postfixed in $4 \%$ paraformaldehyde for $48 \mathrm{~h}$ then stored in $\mathrm{PBS}+0.05 \%$ sodium azide. Fixed half-brains were placed in $30 \%$ sucrose for at least $48 \mathrm{~h}$ before being cut in the coronal plane (40- $\mu \mathrm{m}$ sections) using a freezing sliding microtome. Brain sections were rinsed in PBS before blocking in $\mathrm{PBS}+0.05 \%$ Triton- $\mathrm{X}$ with $10 \%$ goat serum for $1 \mathrm{~h}$. First, samples were stained with AmyloGlo $^{\text {tm }}$ RTD Amyloid Plaque Stain Reagent (Biosensis, Australia) for $15 \mathrm{~min}$, washed three times, and then incubated in pS199 (Abcam, UK, 1:1000) and PHF-1 (gift from Dr. Peter Davis, 1:1000) phospho-tau primary antibodies at $4{ }^{\circ} \mathrm{C}$ overnight. The next day, sections were washed three times with PBS and placed in appropriate Alexa Fluor-conjugated secondary antibody solutions at room temperature for $1 \mathrm{~h}$. Sections were rinsed three additional times, mounted onto slides, and coverslipped using Fluoromount-G. For confocal microscopy, immunofluorescent staining was performed on equivalent brain sections and imaged on the Olympus FX1200 confocal microscope. Tau tangles and $\beta$-amyloid plaques were visualized using Z-stack maximum-projection images taken through the entire depth of the section at 1$\mu \mathrm{m}$ intervals.

\section{Biochemical analyses}

Right hemispheres, previously frozen on dry ice and stored at $-80^{\circ} \mathrm{C}$, were crushed on dry ice using mortar and pestle, then homogenized in solution of T-PER (Thermo Scientific, Waltham, MA) and phosphatase and 
protease inhibitor mixtures (Thermo Scientific, MA and Roche, CA) and processed as previously described [22-24]. Quantitative biochemical analysis of human $A \beta$ was conducted using commercially available electrochemiluminescent multiplex assay system [Meso Scale Discovery (MSD)]. Human $A \beta$ triplex (6E10 capture antibody) was used for simultaneous measurement of $A \beta 38, A \beta 40$, and $A \beta 42$ in both soluble and insoluble protein fractions [24].

Concentrations of human total and phosphorylated tau in samples (soluble and insoluble brain extracts) were determined by Tau (total) Human ELISA kit, Tau [pS396] Human ELISA Kit, Tau [pS199] Human ELISA Kit, Tau [pT181] Human ELISA Kit, and Tau [pT231] Human ELISA Kit (all from ThermoFisher Scientific, $\mathrm{MA})$, according to the manufacturer's instructions.

Soluble SDS-PAGE WB and quantifaction was performed following standard protocols as previously described [22-24]. Primary antibodies used for WB analysis included the following: Armanezumab (1:2000; Institute for Molecular Medicine, Huntington Beach, CA), anti-GFAP (1:500; Millipore-Sigma, MO), antiP2RY12 (1:500; Millipore-Sigma, MO), and anti-CD45 (1:500; Bio-Rad, CA). All blot membranes were also labeled with anti- $\beta$-actin antibodies (1:1000; MilliporeSigma, MO) as a loading control.

\section{Statistical analysis}

All statistical parameters [mean, standard deviation (SD), significant difference, etc.] used in experiments were calculated using Prism 6 software (GraphPad Software, Inc.). Statistically significant differences were examined using unpaired $t$ test or one-way ANOVA with Tukey's multiple comparisons test $(p$ value $<0.05$ was considered as statistically different).

\section{Results}

\section{Immunogenicity of vaccines in T5x mice}

We previously found that a MultiTEP vaccine carrying both $\mathrm{A} \beta$ and tau epitopes together within a single protein, AV-1953R, induced significantly lower titers of anti-tau antibodies in wildtype mice compared with combined delivery of two separate anti-A $\beta$, AV-1959R, and anti-tau, AV-1980R vaccines [10]. Therefore, to test the efficacy of combination therapy, we instead here used a mixture of two vaccines: (1) AV-1959R carrying three copies of $A \beta B$ cell epitope $\left(A \beta_{1-11}\right)$ attached to MultiTEP and (2) AV-1980R, carrying three copies of tau N-terminal epitope $\left(\operatorname{tau}_{2-18}\right)$ attached to MultiTEP, formulated in Advax ${ }^{\mathrm{CpG}}$ adjuvant (AV-1959R/A + AV1980R/A). Two-month-old T5x bigenic mice were immunized with the mixture of both vaccines or with each vaccine separately (Fig. 1). Mice in all groups generated high titers of antibodies specific to $A \beta_{42}$ and/or tau ${ }_{2-18}$ (Fig. 2, Additional file 1: Figure S1). The humoral response in all groups was high, ranging from 55 to $4785 \mu \mathrm{g} / \mathrm{ml}$; however, the average concentrations of anti$\mathrm{A} \beta$ (Fig. 2a) antibodies were significantly lower in mice immunized with the AV-1959R/A + AV-1980R/A combination compared to mice vaccinated with AV-1959R/ A vaccine alone. Similar, but non-significant trend was observed in mice immunized with AV-1980R/A compared with combination vaccines (Fig. $2 \mathrm{~b}$ ). In addition, the antibodies obtained bound equally well in ELISA to both the tau $\mathrm{au}_{2-18}$ peptide and the full-length recombinant tau protein (Fig. $2 \mathrm{~b}, \mathrm{c}$ ). As expected, these vaccines were specific, so immunization with AV-1980R/A alone did not generate anti-A $\beta$ antibodies and immunization with AV-1959R/A alone did not induce production of antitau antibodies (Fig. 2).

Previously, we mapped the epitope for monoclonal antibody generated after immunization of mice with AV-1980R/A [16]. Here, we also mapped the epitopes recognized by antibodies induced in mice vaccinated with AV-1980R/A using alanine scanning. The data demonstrated that in bigenic mice, AV-1980R/A active vaccination generated antibodies specific to two overlapping epitopes comprising amino acids 4-8 (PRQEFE) and 7-13 (EFEVMED) of the N-terminus of human tau (Fig. 3a). The binding avidity of anti-A $\beta_{11}$ polyclonal antibodies generated by AV-1959R/A vaccination in mice [25], rabbits [26], and monkeys [14] to different forms of $A \beta_{42}$ (monomeric, oligomeric, and fibrillar) was previously demonstrated. Thus, in this study, we sought to measure the binding avidity of anti-tau polyclonal antibodies purified from sera of AV-1980R/A vaccinated T5x mice to monomeric and oligomeric forms of recombinant Tau (2N4R) protein. As shown in Fig. 3b, immobilized anti-tau antibodies bound to tau monomers and oligomers with high avidity $(\mathrm{KD}=31.5 \mathrm{pM}$ for monomers and $23.7 \mathrm{pM}$ for oligomers), indicating a marginally higher avidity of the antibodies for tau oligomers than monomers.

Next, we examined whether the immune mouse sera could recognize human senile plaques and tau-laden neurofibrillary tangles, by performing immunofluorescent staining of brain sections of AD case. As expected, sera from T5x mice immunized with AV-1959R/A bound only to amyloid plaque pathology. Conversely, sera from AV-1980R/A-vaccinated mice bound to tau tangles (NFT) and neuritic threads, but not amyloid plaques. Importantly, immune sera from mice vaccinated with the combined vaccines labeled both hallmark pathologies: amyloid plaques and neurofibrillary tangles (Fig. 4). The specific binding of sera (green) to amyloid plaques (blue) and/or NFTs and neuritic threads (red) was further demonstrated by co-labeling brain sections with anti- $\mathrm{A} \beta_{42} \mathrm{Ab}$, a marker of beta-amyloid, and humanized Armanezumab $\mathrm{mAb}$ that is specific to the $\mathrm{N}$ terminal epitope of Tau. Importantly, no binding of $\mathrm{AD}$ 


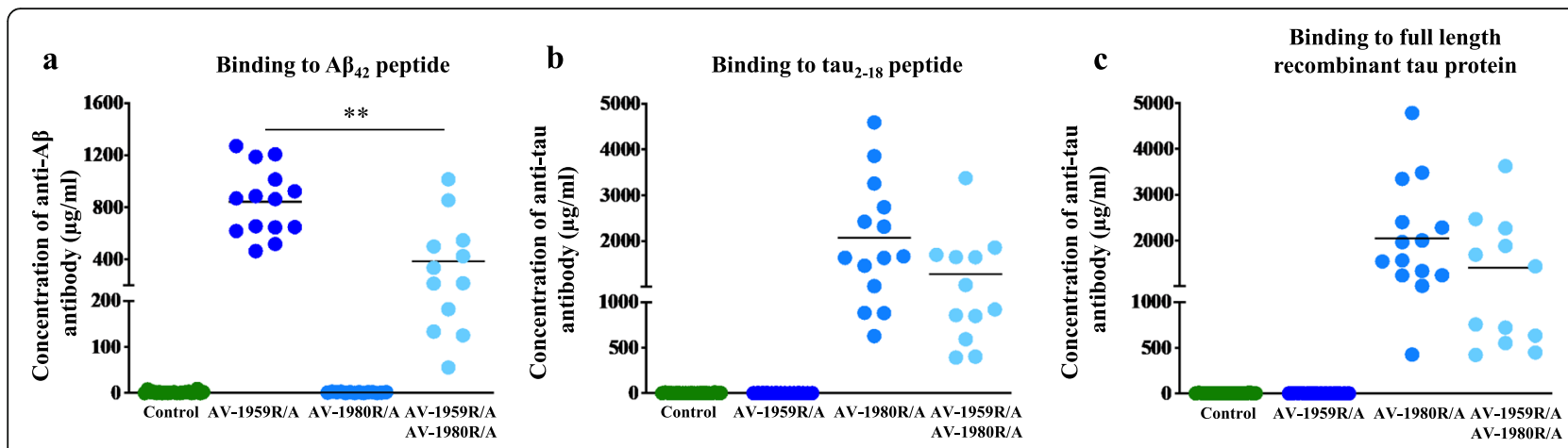

Fig. 2 MultiTEP-based vaccines induced high titers of anti-A $\beta$ and anti-tau antibodies in T5x mice. Concentration of antibodies binding to $A \beta_{42}$

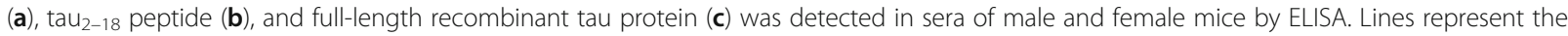
average value for combined male and female mice $\left({ }^{* * *} p \leq 0.001\right)$. Of note, mice immunized with AV-1959R/A did not induce antibodies specific to tau, while vaccination of mice with AV1980R/A did not generate ant-A $\beta$ antibodies

brains was observed with sera from control mice injected with Advax ${ }^{\mathrm{CPG}}$ adjuvant only. Thus, combination therapy with the mixture of MultiTEP-platformbased vaccines can elicit a strong epitope-specific antibody response targeting simultaneously both of the misfolded proteins involved in AD pathology.

\section{Changes in $A \beta$ and tau pathology in the brains of $T 5 x$} mice immunized with single or dual vaccines

Previously, we showed that bigenic T5x mice exhibit accelerated tau pathology compared with the parental THYTau22 strain and reduced insoluble $A \beta_{42}$ compared with parental 5XFAD mice [11]. We analyzed changes in both soluble and insoluble forms of these proteins in brain homogenates from vaccinated mice using sensitive ELISAs for total tau and tau phosphorylated at positions pS199, pT231, pS396, and pT181 and by Meso Scale Discovery (MSD) analysis of $A \beta_{42}, A \beta_{40}$, and $A \beta_{38}$.

Using this approach, we detected a significant reduction in both soluble and insoluble levels of $A \beta_{42}$ in mice immunized with AV-1959R/A (Fig. 5a, d). Mice immunized with a combination vaccine showed a significant reduction of insoluble $A \beta_{42}$ (Fig. $5 \mathrm{~d}$ ). However, when these cohorts were analyzed by gender, we observed a significant reduction of soluble $A \beta_{42}$ in female mice received mixed vaccine, but not AV-1959R/A alone (Additional file 1: Figure S2a), while male mice showed significant reduction of soluble $A \beta_{42}$ in AV-1959R/A cohort and only a slight trend of reduction in $\mathbf{a}$

\begin{tabular}{|lcc|}
\hline Peptide & \multicolumn{2}{c|}{ \% of Inhibition } \\
\hline AEPRQEFEVMEDHAGTY & \multicolumn{2}{c|}{92} \\
\hline SEPRQEFEVMEDHAGTY & 96 & \\
\hline AAPRQEFEVMEDHAGTY & 95.5 & \\
\hline AEARQEFEVMEDHAGTY & 82 & (P) \\
\hline AEPAQEFEVMEDHAGTY & 85 & $(\mathrm{R})$ \\
\hline AEPRAEFEVMEDHAGTY & 97 & \\
\hline AEPRQAFEVMEDHAGTY & No inhibition (E) \\
\hline AEPRQEAEVMEDHAGTY & No inhibition (F) \\
\hline AEPRQEFAVMEDHAGTY & 70 & (E) \\
\hline AEPRQEFEAMEDHAGTY & 35 & (V) \\
\hline AEPRQEFEVAEDHAGTY & 75 & (M) \\
\hline AEPRQEFEVMADHAGTY & 24 & (E) \\
\hline AEPRQEFEVMEAHAGTY & 40 & (D) \\
\hline AEPRQEFEVMEDAAGTY & 90 & \\
\hline AEPRQEFEVMEDHSGTY & 94 & \\
\hline AEPRQEFEVMEDHAATY & 89 & \\
\hline AEPRQEFEVMEDHAGAY & 89 & \\
\hline AEPRQEFEVMEDHAGTA & 93 & \\
\hline
\end{tabular}

는

\section{b}
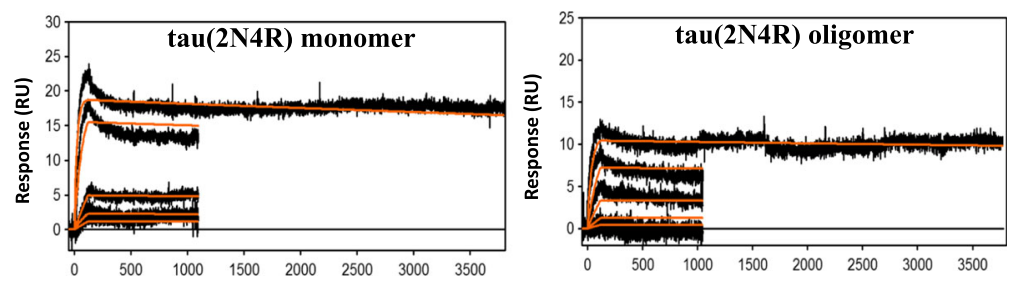

\begin{tabular}{|c|c|c|c|c|c|}
\hline \multicolumn{2}{|c|}{$\mathrm{K}_{\mathrm{a}}$} & \multicolumn{2}{c|}{$\mathrm{K}_{\mathrm{d}}$} & \multicolumn{2}{c|}{$\mathbf{K}_{\mathrm{D}} \mathbf{p M}$} \\
\hline Monomer & Oligomer & Monomer & Oligomer & Monomer & Oligomer \\
\hline $\mathbf{1 . 0 8 8 \times 1 0}^{6}$ & $7.1 \times 10^{5}$ & $3.43 \times 10^{-5}$ & $\mathbf{1 . 6 8 \times 1 0}^{-5}$ & 31.5 & 23.7 \\
\hline
\end{tabular}

\section{A E P R Q E F E V M E D H A G T Y}

Fig. 3 a Epitope mapping of immune sera was performed by alanine scanning competition ELISA. Two overlapped epitopes have been detected comprising amino acids 4-9 PRQEFE and amino acids 7-13 EFEVMED. Percent of inhibition of antibody binding to Tau $\mathrm{U}_{2-18}$ peptide with mutated peptides (alanine substitution of each single amino acid) is shown in the table. $\mathbf{b}$ Binding avidity of anti-tau $\mathrm{u}_{2-18}$ antibodies generated in T5x mice was determined by surface plasmon resonance (SPR). Monomeric and oligomeric forms of recombinant human tau (2N4R) were passed through antibodies immobilized on a Protein A-coated sensor chip 


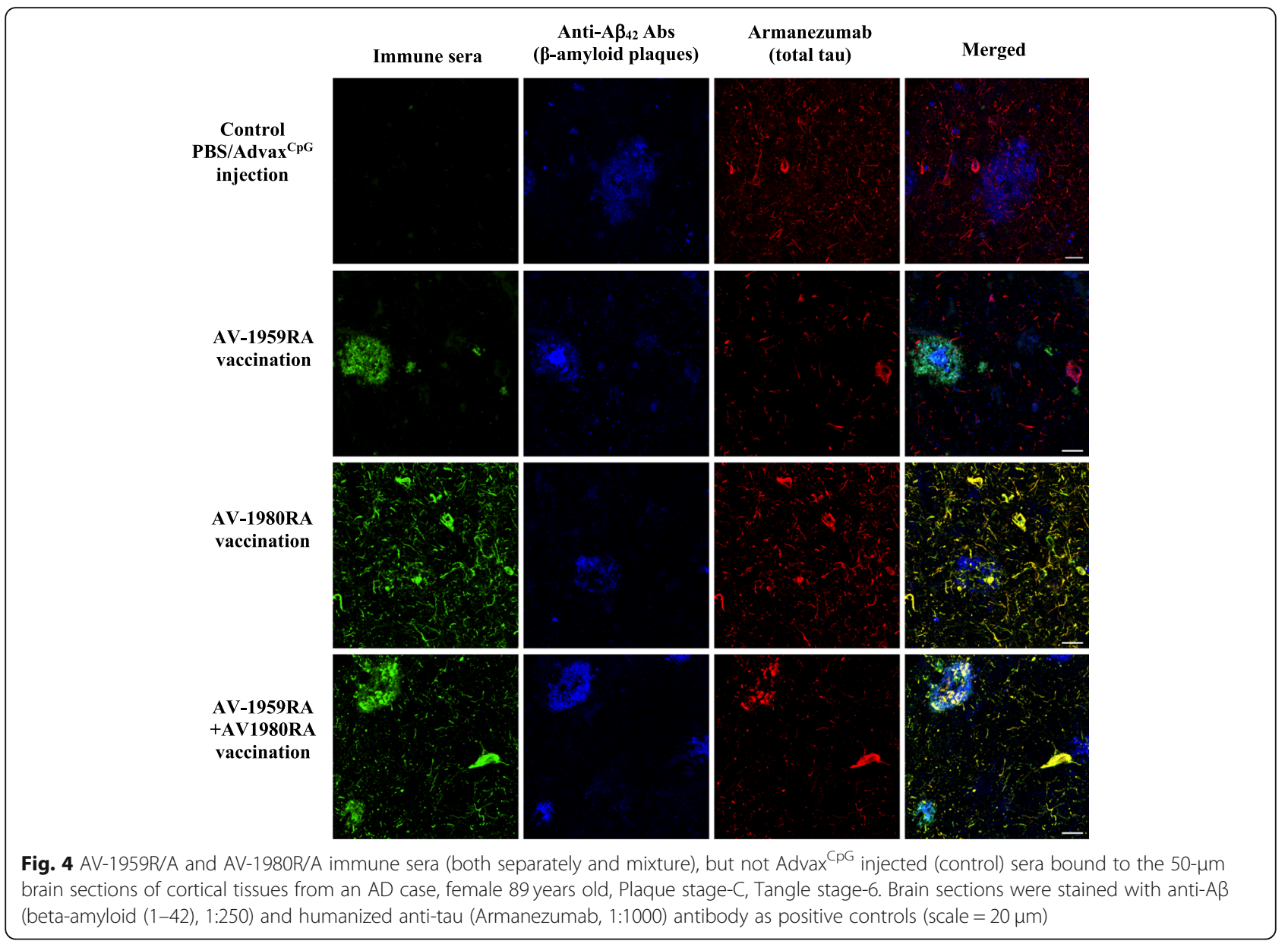

AV-1959R/1980R/A cohort (Additional file 1: Figure S3a), thus making this difference non-significant when combined female/male groups were compared (Fig. 5a). In contrast, insoluble amyloid- $\beta$ was significantly reduced in male mice (Additional file 1: Figure S3d) and showed a wellpronounced downward trend in female mice (Additional file 1: Figure S2d). These data may reflect the sex-dependent impact of antibodies on $A \beta$ pathology. A non-significant trend towards decreased $A \beta_{40}$ (Fig. 5b, e) and $A \beta_{38}$ (Fig. 5c, f) was also observed in mice immunized with AV-1959R/A.

Significant reductions in total and phosphorylated soluble tau were seen in mice treated with the tau vaccine AV-1980R/A as well as mice treated with the vaccine combination, AV-1959R/A + AV-1980R/A (Fig. 6a-e). Interestingly, we also detected significant reductions of several phosphorylated species of tau in mice immunized with the $\beta$-amyloid vaccine, AV-1959R/A, alone (Fig. 6a-c; Additional file 1: Figures S4 and S5), indicating that decreases in $A \beta_{42}$ also led to a decrease of tau pathology, consistent with previous reports in the $3 x \mathrm{Tg}$ AD mouse model [27]. The pattern of reduced species of soluble Tau was slightly different in female and male mice immunized with either anti-A $\beta$ or anti-Tau vaccines alone or in combination (Additional file 1: Figures S4 and S5). These differences could be associated with differences in the pathological burden of $A \beta$ and Tau in mice of different genders as well as the titers of induced antibodies. Female mice have higher levels of $\mathrm{A} \beta_{42}$, but lower levels of Tau than male mice. Additional studies that employ greater numbers of both male and female mice will be needed to fully characterize the potential differential changes that occur between male and female immunized T5x mice. Regardless of these intriguing sex-dependent differences, the reduction of all analyzed soluble tau species in the combined gender groups demonstrates the robust effect on multiple tau species achieved by this approach.

Analysis of insoluble species of $A \beta$ and Tau also revealed sex-dependent effects of vaccination. Although vaccinated female mice showed a downward trend in both $\mathrm{A} \beta_{42}$ and tau molecules, a significant reduction was observed only in male mice (Additional file 1: Figure S4f-g; Figure S5f-j) leading to significant decrease in the combined male and female groups for all detected insoluble tau species (Fig. $6 f-j$ and Additional file 1: Figure S4e). 


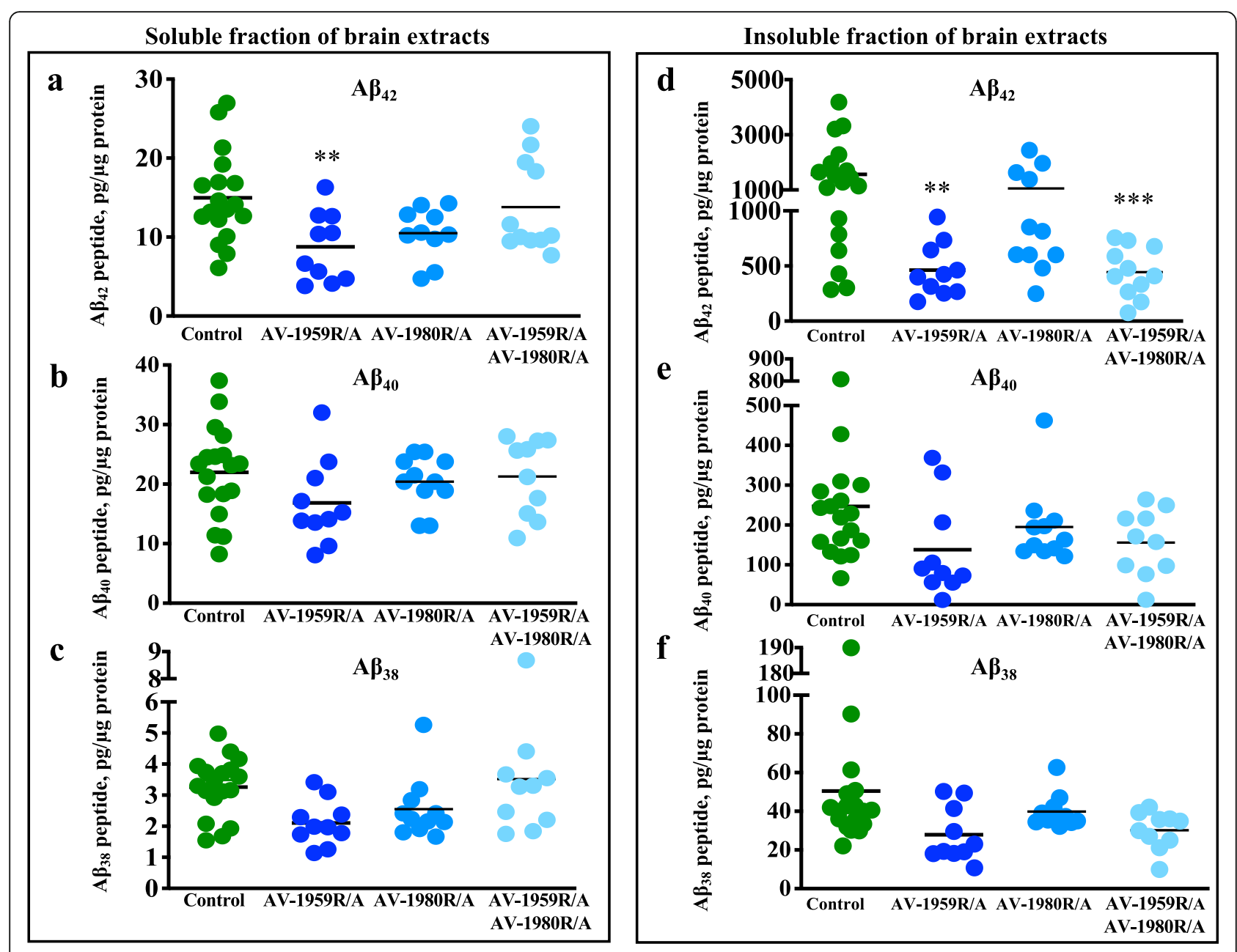

Fig. 5 Effect of protein vaccination on $A \beta$ proteins in $T 5 x$ mice. Level of human $A \beta_{42}(\mathbf{a}, \mathbf{d}), A \beta_{40}(\mathbf{b}, \mathbf{e})$, and $A \beta_{38}(\mathbf{c}, \mathbf{f})$ peptides in brain soluble $(\mathbf{a}-\mathbf{c})$ and insoluble $(\mathbf{d}-\mathbf{f})$ extractions were analyzed by MSD assay. Lines represent average $\left({ }^{*} p \leq 0.05 ;{ }^{*} p \leq 0.01\right)$

To determine whether immunization might lead to changes in microgliosis and astrocytosis, we performed WB with antibodies specific to GFAP, P2RY12, and CD45 (Additional file 1: Figure S6). Somewhat suprisingly, no differences were detected in the expression of the astrocytic activation marker GFAP, the microglial homoeostatic marker P2RY12, or the myeloid activation marker CD45, between control and vaccinated $\mathrm{T} 5 \mathrm{x}$ mice. These data suggest that although antibody-mediated reduction in pathology can be expected to decrease glial activation, betaamyloid and tau antibodies may alternatively offset any such response by activating microglia via Fc-mediated signaling. Thus, these potentially apposing effects might result in no significant changes in glial activation.

As ELISA measurements provide a more quantitative approach than histology, we used ELISA to measure soluble and insoluble $A \beta$, tau, and phospho-tau species to determine the effectiveness of the AV-1959R/A, AV1980R/A, and combined vaccination approach. However, we also asked whether an immunohistochemical and confocal microscopy approach might provide a further indication of altered pathology. Sections from 3 mice per group were examined using double-labeling for PHF-1 and pS199 tau along with Amylo-Glo, a Thioflavin S analog that labels the beta-pleated sheet confirmation of amyloid plaques. Confocal Z-stacks were captured, with representative images (Additional file 1: Figure S7) indicating that $\mathrm{AV}-1959 \mathrm{R} / \mathrm{A}$ vaccination or the combined AV-1959R/A + AV-1980R/A approach successfully reduced both $A \beta$ and tau pathology. In contrast, vaccination with AV-1980R/A alone reduced Tau pathology but not $A \beta$ plaques, as would be expected from the biochemical data detailed above (Fig. 5).

\section{Discussion}

Despite some encouraging clinical data for BAN2401 monoclonal antibody (mAb), which selectively binds large soluble $A \beta$ protofibrils [28], the vast majority of $A \beta$ therapeutics trials, including but not limited to active and passive vaccines, have thus far failed to modify 


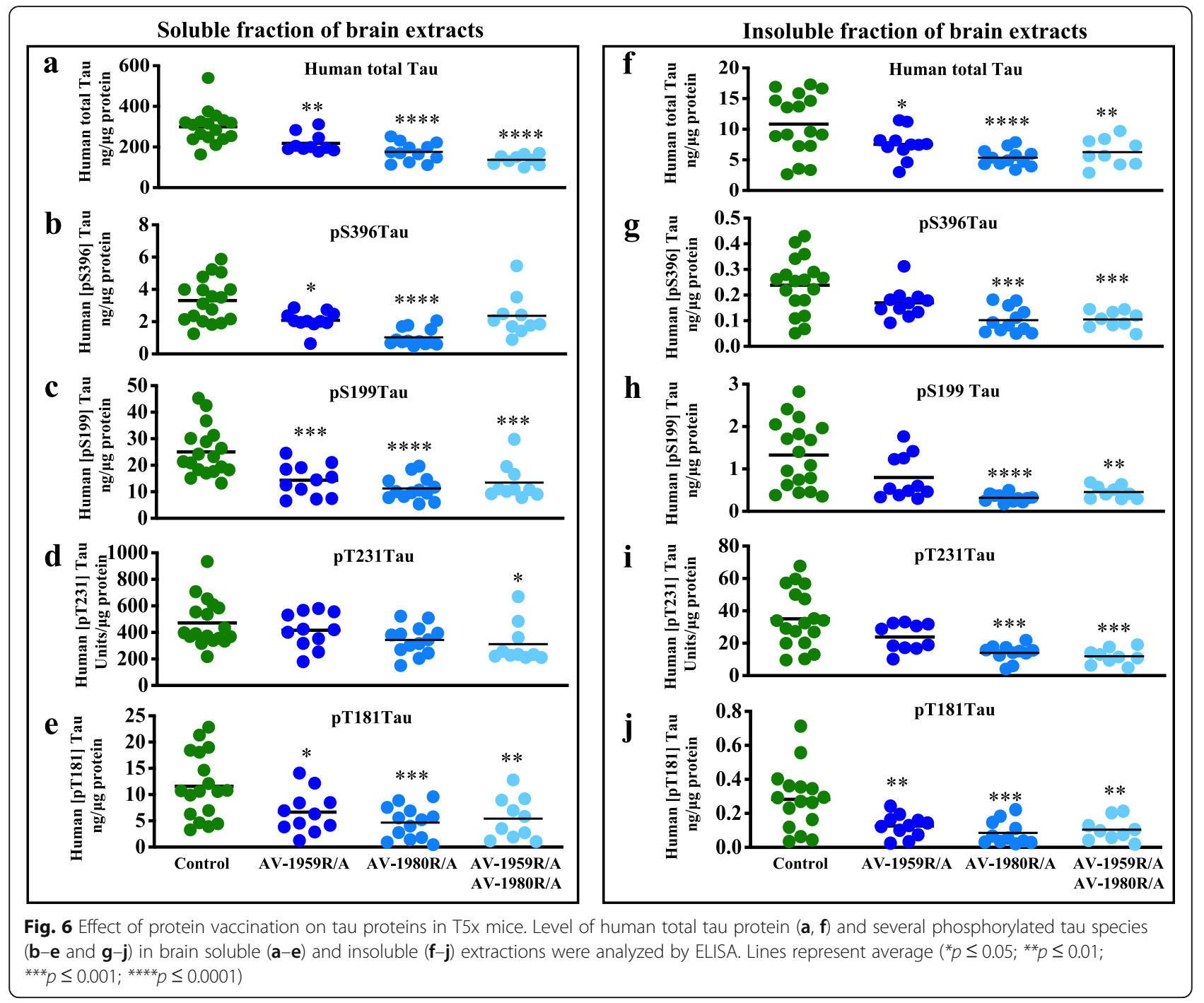

cognition in $\mathrm{MCI}$ and $\mathrm{AD}$ subjects [29-31]. The failure of these trials may reflect treatment being initiated too late in the pathological process when neuronal damage or other downstream pathologies cannot be reversed. Therefore, thinking has moved to the idea that $\mathrm{A} \beta$-based mono treatment should be initiated as a preventive rather than a therapeutic measure. Such a long-term prophylactic strategy could likely only be practically achieved in terms of both compliance and affordability, through the use of a safe and immunogenic vaccine rather than monoclonal antibody infusions [28, 30, 32-38]. Nevertheless, based on the recently published data indicating that $A \beta$ and tau aggregates interact synergistically to drive downstream neurodegeneration $[1,2,9,39,40]$, we hypothesize that vaccines targeting both pathological molecules simultaneously might be the most effective therapeutic approach [10].

The current study tested the immunogenicity of AV1959R/A and AV-1980R/A as a combined vaccine in the T5x bigenic mouse model of $\mathrm{AD}$ which exhibits robust accumulation of intraneuronal tau and extensive extracellular amyloid plaque pathology within the hippocampus, neocortex, and amygdala by 7 months of age [11]. By comparison with wildtype mice [10], humoral immune responses in bigenic mice vaccinated either with AV-1959R/A or with AV-1980R/A alone were higher than in mice vaccinated with combined vaccines (Fig. 2 and Additional file 1: Figure S1). Notably, combined vaccines formulated in Advax ${ }^{\mathrm{CpG}}$ adjuvant successfully generated high concentrations (55 to $4785 \mu \mathrm{g} / \mathrm{ml}$ ) of antibodies specific to both $\mathrm{A} \beta$ and tau (Fig. 2 and Additional file 1: Figure S1). These milligram levels of antibodies in the sera of vaccinated animals are due to the MultiTEP vaccine platform that strongly activates $\mathrm{T}$ helper cells in mice of $\mathrm{H}-2^{\mathrm{b}}$ immune haplotype [10, 41]. Importantly, this universal MultiTEP vaccine platform is designed to provide a broad coverage of human MHC class II polymorphism by utilizing a wide array of tetanus toxin, hepatitis B, and influenza Th epitopes 
incorporated into the MultiTEP platform [26]. These foreign Th epitopes incorporated into the MultiTEP platform are very immunogenic in mice of different haplotypes, in rabbits, and in monkeys with highly polymorphic MHC class II genes [14, 22, 26, 41, 42]. A growing amount of evidence suggests that prophylactic vaccination delivered prior to clinical symptoms may be needed to prevent the development of AD fully. However, therapeutic treatments that target amyloid and tau pathology and alleviate key symptoms and/or slow the progression of $\mathrm{AD}$ are still desperately needed to treat the millions of people currently affected by AD. Yet, it is well known that older people respond poorly to new vaccines due to immunosenescence, characterized by an abundance of memory $\mathrm{T}$ cells and a decrease in the number of naive $\mathrm{T}$ cells with age [43]. The MultiTEP strategy provides a unique opportunity to generate high levels of antibodies in the elderly by activating not only naïve Th cells, but also pre-existing memory Th cells previously generated in response to infections and/or vaccinations with tetanus toxin, hepatitis B, and influenza, thereby overcoming immunosenescence. Indeed, the feasibility of this strategy based on pre-existing memory Th cells was previously demonstrated [10, 21, 44].

Earlier, we demonstrated that in mice and monkeys, AV-1959 induced antibodies specific to the AEFRH epitope of $A \beta_{1-11}$ peptide incorporated in this vaccine [41]. This immunodominant $\mathrm{B}$ cell epitope of $\mathrm{N}$-terminus of $\mathrm{A} \beta_{42}$ [45] is widely used in preclinical and clinical studies, and data from various groups, including us, suggest that high-affinity antibodies specific to this region reduce AD-like pathology not only in mouse models of AD but also in brains of vaccinated people $[18,20,21$, 25, 44, 46-51]. Immunizations with AV-1959R/A also induced therapeutically potent antibodies that significantly reduced soluble and insoluble $A \beta_{42}$ pathology in this pathologically aggressive bigenic mouse model of AD (Fig. 5).

Here, we also mapped the immunogenic B cell epitopes of $\mathrm{tau}_{2-18}$ and demonstrated that antibodies induced by AV-1980R/A recognized two overlapping epitopes comprising $4-8$ aa and $7-13$ aa (Fig. 3). The later epitope coincides with that of the TNT1 mAb, which is shown to recognize pre-tangle pathology in early Braak stages and more compact classical neurofibrillary tangles, but not late-stage ghost tangles [17]. We previously compared the binding of Armanezumab, mAb specific to aa 4-8, with TNT1 and showed that, under denaturing conditions, both antibodies bind to tau protein in $\mathrm{AD}$, but not in non-AD brains. However, under denaturing conditions, Armanezumab recognizes tau aggregates with a higher molecular weight compared to TNT1 [16]. Thus, we believe that AV-1980R/A, which induces antibodies specific to two B cell epitopes, might be therapeutically more effective than the mAb. In fact, in the stringent $\mathrm{T} 5 \mathrm{x}$ bigenic mouse model of $\mathrm{AD}$ used here, AV-1980R/A vaccine has induced high-affinity antibodies (Fig. 3) that significantly decreased soluble and insoluble total and various phosphorylated tau species in the brains of vaccinated animals (Fig. 6).

We expected that neuropathological changes in the brains of mice immunized with a combination vaccine would be more pronounced compared to single vaccinated mice, but the reduction in $A \beta_{42}$ and various tau species was comparable in mice immunized with either a single or a combination vaccine. Perhaps this can be explained by data showing that the combined vaccine generated lower titers of anti- $\mathrm{A} \beta$ and anti-tau antibodies in mice than single vaccines (Fig. 2). Nevertheless, we anticipate that a simultaneous reduction of both pathological molecules may lead to a better improvement in cognitive functions, although future studies will need to carefully test this question in appropriate mouse models. Such behavioral studies may need to be tested in a less aggressive mouse model that better reflects the more common, sporadic form of Alzheimer's disease in which the time window for effective prevention and treatment is likely wider, e.g., APP knock-in mice crossbred with humanized Tau knock-in mice [52-57]. As cognitive deficits tend to develop at later ages in knock-in models, these mice likely represent models of preclinical AD that could be well suited for testing preventative active vaccines.

Interestingly, we observed a significant decrease of tau in mice immunized with a single vaccine targeting $A \beta$, AV-1959R/A (Fig. 6), but did not see decreased $A \beta_{42}$ in mice immunized with single anti-tau vaccine, AV-1980R/ A (Fig. 5). This data, as well as pervious data showing a threefold increase in misfolded and hyperphosphorylated tau in mice generated by crossing of Thy-Tau 22 with $5 x F A D$ mice [11] further, supports the hypothesis that $A \beta$ can accelerate and exacerbate tau pathology.

\section{Conclusions}

Here, we showed that combined active vaccine based on the MultiTEP platform and formulated with Advax ${ }^{\mathrm{CpG}}$ adjuvant, which has been shown to be safe and effective in human trials [58-61], is highly immunogenic in bigenic mice exhibiting both $\mathrm{A} \beta$ and tau pathologies. Generated antibodies specifically recognize $A \beta$ plaques, neurofibrillary tangles, and neuritic threads in human $\mathrm{AD}$ tissue, and most importantly, vaccination leads to significant decreases in multiple soluble and insoluble tau species and insoluble $A \beta_{42}$ in the brains of transgenic mice. This data suggests that a combined vaccination approach could potentially be used to induce strong immune responses against both of the hallmark pathologies of $\mathrm{AD}$ in a broad population of vaccinated subjects with high MHC class II gene polymorphisms. 


\section{Supplementary information}

Supplementary information accompanies this paper at https://doi.org/10. 1186/s13195-019-0556-2

Additional file 1: Figure S1. Humoral immune responses in female and male $T 5 x$ mice vaccinated with different vaccines. Concentration of antibodies binding to $A \beta 42(a, d)$, tau2-18 peptide $(b, e)$ and full-length recombinant tau protein $(c, f)$ were detected in sera by ELISA. Lines represent average. Statistically significant differences were examined using unpaired $t$-test $\left({ }^{* *} p \leq 0.01\right.$; Control group $-n=8$ for female and $n=14$ for male; AV-1959R/A group $-n=6$ for female and $n=8$ for male, AV-1980R/A group $-\mathrm{n}=6$ for female and $\mathrm{n}=8$ for male and AV-1959R/A+AV-1980RA group $-n=5$ for female and $n=7$ for male). Figure $\mathbf{S 2}$. Effect of protein vaccination on $A \beta$ proteins in female, $T 5 x$ mice. Level of human $A \beta 42$ (a and $d$ ), $A \beta 40$ ( $b$ and e) and $A \beta 38$ ( $c$ and $f$ ) peptides in brain soluble ( $a-c)$ and insoluble ( $d-f)$ extractions were analyzed by MSD assay. Error bars represent average \pm SEM. Statistically significance were calculated against Control group using ANOVA test $\left({ }^{*} p \leq 0.01\right.$; Control group $-\mathrm{n}=8$ for female and $n=14$ for male; AV-1959R/A group $-n=6$ for female and $n=8$ for male, AV-1980R/A group $-n=6$ for female and $n=8$ for male and AV1959R/A+AV-1980RA group $-n=5$ for female and $n=7$ for male). Figure S3. Effect of protein vaccination on $A \beta$ proteins in male, T5x mice. Level of human $A \beta 42$ ( $a$ and $d$ ), $A \beta 40$ ( $b$ and $e$ ) and $A \beta 38$ ( $c$ and $f$ ) peptides in brain soluble $(a-c)$ and insoluble ( $d-f)$ extractions were analyzed by MSD assay. Error bars represent average \pm SEM. Statistically significance were calculated against Control group using ANOVA test $\left({ }^{*} p \leq 0.05 ;{ }^{* * *} p \leq\right.$ 0.001; Control group $-n=8$ for female and $n=14$ for male; AV-1959R/A group $-\mathrm{n}=6$ for female and $\mathrm{n}=8$ for male, AV-1980R/A group $-\mathrm{n}=6$ for female and $n=8$ for male and AV-1959R/A+AV-1980RA group $-n=5$ for female and $n=7$ for male). Figure S4. Effect of protein vaccination on tau proteins in female, T5x mice. Level of human total tau protein $(\mathrm{a}, \mathrm{f})$ and several phosphorylated tau species (b-e and g-j) in brain soluble (a-e) and insoluble (fj) extractions were analyzed by ELISA. Error bars represent average \pm SEM. Statistically significance were calculated against Control group using ANOVA test $\left({ }^{*} p \leq 0.05 ;{ }^{* *} p \leq 0.01 ;{ }^{* * *} p \leq 0.001 ;{ }^{* * * *} p \leq\right.$ 0.0001; Control group $-\mathrm{n}=8$ for female and $n=14$ for male; AV-1959R/A group $-\mathrm{n}=6$ for female and $n=8$ for male, AV-1980R/A group $-n=6$ for female and $n=8$ for male and AV-1959R/A+AV-1980RA group $-n=5$ for female and $n=7$ for male). Figure S5. Effect of protein vaccination on tau proteins in male, $T 5 x$ mice. Level of human total tau protein $(a, f)$ and several phosphorylated tau species (b-e and $\mathrm{g}$-j) in brain soluble (a-e) and insoluble (fj) extractions were analyzed by ELISA. Error bars represent average \pm SEM. Statistically significance were calculated against Control group using ANOVA test ( ${ }^{*} p \leq 0.05 ;{ }^{* *} p \leq 0.01 ;{ }^{* * *} p \leq 0.001 ;{ }^{* * * *} p \leq$ 0.0001; Control group $-\mathrm{n}=8$ for female and $n=14$ for male; AV-1959R/A group $-\mathrm{n}=6$ for female and $n=8$ for male, AV-1980R/A group $-\mathrm{n}=6$ for female and $n=8$ for male and AV-1959R/A+AV-1980RA group - $n=5$ for female and $n=7$ for male). Figure S6. Vaccination with protein vaccines did not change astrogliosis and microgliosis in brains of T5x mice. The levels of GFAP, P2RY12 and CD45 proteins in the soluble fraction of the brain extracts were analyzed by Western blotting and quantitatively determined by densitometric analysis with normalization against $\beta$-actin. The relative protein level in the brains of vaccinated mice is presented as a percentage of the protein level in the brains of control mice. Error bars represent average \pm SEM. Statistically significant differences were examined using one-way ANOVA ( $n=12$ for Control group and $n=11$ for all vaccinated groups). Figure S7. Reduced $\beta$-amyloid and tau pathology in T5x mice following vaccination with different proteins. Representative pictures of brain CA1 region immunostained for Amylo-GloTM (ThS, anti-

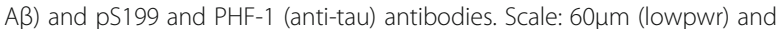
$15 \mu \mathrm{m}$ (highpwr).

\section{Abbreviations}

AD: Alzheimer disease; A $\beta$ : $\beta$-Amyloid; PHF: Paired helical filaments; T5x: Tau22-5xFAD mice; ELISA: Enzyme-linked immunosorbent assay; MSD: Meso Scale Discovery assay; PART: Primary age-related tauopathy; Th: T helper; NIA-AA: Alzheimer's Association published revised guidelines; PET: Positron emission tomography; APP: Amyloid- $\beta$ precursor protein; MCl: Mild Cognitive Impairment; ADNI: Alzheimer's Disease Neuroimaging Initiative; SNAP: Suspected Non-Alzheimer Pathology; MHC: Major
Histocompatibility Complex; HBV: Hepatitis B virus; TNT1: Tau N-terminal 1; E. coli: Escherichia coli; WB: Western blot; SPR: Surface plasmon resonance; PBS: Phosphate-buffered saline; HRP: Enzyme horseradish peroxidase; TMB: 3,3',5,5'Tetramethylbenzidine; BSA: Bovine serum albumin; SD: Standard deviation; SEM: Standard error of the mean

\section{Acknowledgements}

We thank Drs. Luc Buée and David Blum (University of Lille, Inserm, France) for generously providing the parental Thy1-Tau22 transgenic mouse model.

\section{Authors' contributions}

$H D, D H C, M G A, M B J$, and AG designed the research; HD, AH, SKS, TA, KZ, GC, $I P, O S$, and ED performed the research; $H D, M A C, N P, D C, M G A, M B J$, and $A G$ analyzed the data; $H D, M G A, M B J$, and $A G$ wrote the paper. All authors have read and approved the final manuscript for publication.

\section{Funding}

This work was supported by funding from NIH (R01-NS050895, R01AG020241, U01-AG060965, R21-NS101504, R01-AG061895, RF1-AG048099, R01-AG055524, R01-AG056303, P50-AG016573). Development of Advax ${ }^{\text {CPG }}$ adjuvant was supported by funding from NIAID/NIH (Contract No. HHSN272201400053C, HHS-N272200800039C, and U01-Al061142). The content is solely the responsibility of the authors and does not necessarily represent the official views of the $\mathrm{NIH}$.

\section{Availability of data and materials}

All data generated or analyzed during this study are included in this published article and its supplementary information files.

\section{Ethics approval and consent to participate}

All animal studies are conducted in accordance with the NIH, American Physiological Society, and University of California, Irvine Animal Care Guidelines. The University of California, Irvine, animal assurance number is A3416-01.

\section{Consent for publication}

Not applicable

\section{Competing interests}

MGA and AG are co-founders of Capo Therapeutics that licensed MultiTEP vaccine platform technology from the Institute for Molecular Medicine. NP is a founder of Vaxine that developed $A d v a x{ }^{C p G}$ adjuvant. The remaining authors declare that they have no competing interests.

\section{Author details}

${ }^{1}$ Department of Molecular Immunology, Institute for Molecular Medicine, Huntington Beach, CA, USA. ${ }^{2}$ Institute for Memory Impairments and Neurological Disorders, University of California, Irvine, Irvine, CA, USA. ${ }^{3}$ Sue and Bill Gross Stem Cell Research Center, University of California, Irvine, Irvine, CA, USA. ${ }^{4}$ Department of Neurobiology and Behavior, University of California, Irvine, Irvine, CA, USA. ${ }^{5}$ Current address: Department of Pharmaceutical Sciences, College of Pharmacy, University of Nebraska Medical Center, Omaha, NE, USA. ${ }^{6}$ School of Biological Sciences, University of California, Irvine, Irvine, CA, USA. ${ }^{7}$ Flinders University and Vaxine Pty Ltd, Adelaide, Australia.

Received: 21 June 2019 Accepted: 11 November 2019 Published online: 17 December 2019

\section{References}

1. Pascoal TA, Mathotaarachchi S, Mohades S, Benedet AL, Chung CO, Shin M, Wang S, Beaudry T, Kang MS, Soucy JP, et al. Amyloid-beta and hyperphosphorylated tau synergy drives metabolic decline in preclinical Alzheimer's disease. Mol Psychiatry. 2017;22:306-11.

2. Pascoal TA, Mathotaarachchi S, Shin M, Benedet AL, Mohades S, Wang S, Beaudry T, Kang MS, Soucy JP, Labbe A, et al. Synergistic interaction between amyloid and tau predicts the progression to dementia. Alzheimers Dement. 2017;13:644-53

3. Bejanin A, Schonhaut DR, La Joie R, Kramer JH, Baker SL, Sosa N, Ayakta N, Cantwell A, Janabi M, Lauriola M, et al. Tau pathology and 
neurodegeneration contribute to cognitive impairment in Alzheimer's disease. Brain. 2017;140:3286-300.

4. Nelson PT, Alafuzoff I, Bigio EH, Bouras C, Braak H, Cairns NJ, Castellani RJ, Crain BJ, Davies P, Del Tredici K, et al. Correlation of Alzheimer disease neuropathologic changes with cognitive status: a review of the literature. J Neuropathol Exp Neurol. 2012;71:362-81.

5. Jack CR Jr, Bennett DA, Blennow K, Carrillo MC, Dunn B, Haeberlein SB, Holtzman DM, Jagust W, Jessen F, Karlawish J, et al. NIA-AA research framework: toward a biological definition of Alzheimer's disease. Alzheimers Dement. 2018;14:535-62

6. Jack CR Jr, Knopman DS, Jagust WJ, Petersen RC, Weiner MW, Aisen PS, Shaw LM, Vemuri P, Wiste HJ, Weigand SD, et al. Tracking pathophysiological processes in Alzheimer's disease: an updated hypothetical model of dynamic biomarkers. Lancet Neurol. 2013;12:207-16.

7. Jack CR Jr, Knopman DS, Jagust WJ, Shaw LM, Aisen PS, Weiner MW Petersen RC, Trojanowski JQ. Hypothetical model of dynamic biomarkers of the Alzheimer's pathological cascade. Lancet Neurol. 2010;9:119-28.

8. Kaufman SK, Sanders DW, Thomas TL, Ruchinskas AJ, Vaquer-Alicea J, Sharma AM, Miller TM, Diamond MI. Tau prion strains dictate patterns of cell pathology, progression rate, and regional vulnerability in vivo. Neuron. 2016;92:796-812.

9. Hanseeuw BJ, Betensky RA, Jacobs HIL, Schultz AP, Sepulcre J, Becker JA, Cosio DMO, Farrell M, Quiroz YT, Mormino EC, et al. Association of amyloid and tau with cognition in preclinical Alzheimer disease: a longitudinal study. JAMA Neurol. 2019;76(8):986.

10. Davtyan H, Zagorski K, Rajapaksha H, Hovakimyan A, Davtyan A, Petrushina I, Kazarian K, Cribbs DH, Petrovsky N, Agadjanyan MG, Ghochikyan A. Alzheimer's disease Advax (CpG)- adjuvanted MultiTEP-based dual and single vaccines induce high-titer antibodies against various forms of tau and Abeta pathological molecules. Sci Rep. 2016;6:28912.

11. Chen W, Abud EA, Yeung ST, Lakatos A, Nassi T, Wang J, Blum D, Buee L, Poon WW, Blurton-Jones M. Increased tauopathy drives microglia-mediated clearance of beta-amyloid. Acta Neuropathol Commun. 2016;4:63.

12. Oakley H, Cole SL, Logan S, Maus E, Shao P, Craft J, Guillozet-Bongaarts A, Ohno M, Disterhoft J, Van Eldik L, et al. Intraneuronal beta-amyloid aggregates, neurodegeneration, and neuron loss in transgenic mice with five familial Alzheimer's disease mutations: potential factors in amyloid plaque formation. J Neurosci. 2006;26:10129-40.

13. Schindowski K, Bretteville A, Leroy K, Begard S, Brion JP, Hamdane M, Buee L. Alzheimer's disease-like tau neuropathology leads to memory deficits and loss of functional synapses in a novel mutated tau transgenic mouse without any motor deficits. Am J Pathol. 2006;169:599-616.

14. Evans CF, Davtyan H, Petrushina I, Hovakimyan A, Davtyan A, Hannaman D, Cribbs DH, Agadjanyan MG, Ghochikyan A. Epitope-based DNA vaccine for Alzheimer's disease: translational study in macaques. Alzheimers Dement. 2014;10:284-95.

15. Davtyan H, Mkrtichyan M, Movsesyan N, Petrushina I, Mamikonyan G, Cribbs $\mathrm{DH}$, Agadjanyan MG, Ghochikyan A. DNA prime-protein boost increased the titer, avidity and persistence of anti-Abeta antibodies in wild-type mice. Gene Ther. 2010;17:261-71.

16. Agadjanyan MG, Zagorski K, Petrushina I, Davtyan H, Kazarian K, Antonenko M, Davis J, Bon C, Blurton-Jones M, Cribbs DH, Ghochikyan A. Humanized monoclonal antibody armanezumab specific to N-terminus of pathological tau: characterization and therapeutic potency. Mol Neurodegener. 2017;12:33.

17. Combs B, Hamel C, Kanaan NM. Pathological conformations involving the amino terminus of tau occur early in Alzheimer's disease and are differentially detected by monoclonal antibodies. Neurobiol Dis. 2016;94:18-31.

18. Movsesyan N, Ghochikyan A, Mkrtichyan M, Petrushina I, Davtyan H, Olkhanud PB, Head E, Biragyn A, Cribbs DH, Agadjanyan MG. Reducing ADlike pathology in 3xTg-AD mouse model by DNA epitope vaccine- a novel immunotherapeutic strategy. PLoS One. 2008;3:e21-4.

19. Davtyan H, Hovakimyan A, Zagorski K, Davtyan A, Petrushina I, Agdashian D, Murthy V, Cribbs DH, Agadjanyan MG, Ghochikyan A. BTX AgilePulse(TM) system is an effective electroporation device for intramuscular and intradermal delivery of DNA vaccine. Curr Gene Ther. 2014;14:190-9.

20. Petrushina I, Ghochikyan A, Mktrichyan M, Mamikonyan G, Movsesyan N, Davtyan H, Patel A, Head E, Cribbs DH, Agadjanyan MG. Alzheimer's disease peptide epitope vaccine reduces insoluble but not soluble/oligomeric a\{beta\} species in amyloid precursor protein transgenic mice. J Neurosci. 2007;27:12721-31.

21. Davtyan H, Ghochikyan A, Petrushina I, Hovakimyan A, Davtyan A, Poghosyan A, Marleau AM, Movsesyan N, Kiyatkin A, Rasool S, et al. Immunogenicity, efficacy, safety, and mechanism of action of epitope vaccine (Lu AF20513) for Alzheimer's disease: prelude to a clinical trial. J Neurosci. 2013;33:4923-34

22. Davtyan H, Chen WW, Zagorski K, Davis J, Petrushina I, Kazarian K, Cribbs DH, Agadjanyan MG, Blurton-Jones M, Ghochikyan A. MultiTEP platform-based DNA epitope vaccine targeting $\mathrm{N}$-terminus of tau induces strong immune responses and reduces tau pathology in THY-Tau22 mice. Vaccine. 2017;35:2015-24.

23. Blurton-Jones M, Kitazawa M, Martinez-Coria H, Castello NA, Muller FJ, Loring JF, Yamasaki TR, Poon WW, Green KN, LaFerla FM. Neural stem cells improve cognition via BDNF in a transgenic model of Alzheimer disease. Proc Natl Acad Sci U S A. 2009;106:13594-9.

24. Marsh SE, Abud EM, Lakatos A, Karimzadeh A, Yeung ST, Davtyan H, Fote GM, Lau L, Weinger JG, Lane TE, et al. The adaptive immune system restrains Alzheimer's disease pathogenesis by modulating microglial function. Proc Natl Acad Sci U S A. 2016;113:E1316-25.

25. Mamikonyan G, Necula M, Mkrtichyan M, Ghochikyan A, Petrushina I, Movsesyan N, Mina E, Kiyatkin A, Glabe C, Cribbs DH, Agadjanyan MG. AntiAbeta 1-11 antibody binds to different beta-amyloid species, inhibits fibril formation, and disaggregates preformed fibrils, but not the most toxic oligomers. J Biol Chem. 2007:282:22376-86.

26. Ghochikyan A, Davtyan H, Petrushina I, Hovakimyan A, Movsesyan N, Davtyan A, Kiyatkin A, Cribbs DH, Agadjanyan MG. Refinement of a DNA based Alzheimer's disease epitope vaccine in rabbits. Hum Vaccin Immunother. 2013;9:1002-10.

27. Oddo S, Caccamo A, Shepherd JD, Murphy MP, Golde TE, Kayed R, Metherate R, Mattson MP, Akbari Y, LaFerla FM. Triple-transgenic model of Alzheimer's disease with plaques and tangles: intracellular Abeta and synaptic dysfunction. Neuron. 2003;39:409-21.

28. Swanson CJ, Zhang Y, Dhadda S, Wang J, Kaplow J, Lai RYK, Lannfelt L, Kramer L, Luthman J. Treatment of early AD subjects with BAN2401, an anti$A \beta$ protofibril monoclonal antibody, significantly clears amyloid plaque and reduces clinical decline. Alzheimers Dement. 2018;14(7):1668.

29. Selkoe DJ. Alzheimer disease and aducanumab: adjusting our approach. Nat Rev Neurol. 2019;15:365-6.

30. Panza F, Lozupone M, Dibello V, Greco A, Daniele A, Seripa D, Logroscino G, Imbimbo BP. Are antibodies directed against amyloid-beta (Abeta) oligomers the last call for the Abeta hypothesis of Alzheimer's disease? Immunotherapy. 2019;11:3-6.

31. Mo JJ, Li JY, Yang Z, Liu Z, Feng JS. Efficacy and safety of anti-amyloid-beta immunotherapy for Alzheimer's disease: a systematic review and network meta-analysis. Ann Clin Transl Neurol. 2017;4:931-42.

32. Tarawneh R, Holtzman DM. Critical issues for successful immunotherapy in Alzheimer's disease: development of biomarkers and methods for early detection and intervention. CNS Neurol Disord Drug Targets. 2009;8:144-59.

33. Wisniewski T. AD vaccines: conclusions and future directions. CNS Neurol Disord Drug Targets. 2009;8:160-6.

34. Kokjohn TA, Roher AE. Antibody responses, amyloid-beta peptide remnants and clinical effects of AN-1792 immunization in patients with $A D$ in an interrupted trial. CNS Neurol Disord Drug Targets. 2009;8:88-97.

35. Sevigny J, Chiao P, Bussiere T, Weinreb PH, Williams L, Maier M, Dunstan R, Salloway $S$, Chen T, Ling Y, et al. The antibody aducanumab reduces Abeta plaques in Alzheimer's disease. Nature. 2016;537:50-6.

36. Parsons CG, Danysz W, Dekundy A, Pulte I. Memantine and cholinesterase inhibitors: complementary mechanisms in the treatment of Alzheimer's disease. Neurotox Res. 2013:24:358-69.

37. Van Bulck M, Sierra-Magro A, Alarcon-Gil J, Perez-Castillo A, Morales-Garcia JA. Novel approaches for the treatment of Alzheimer's and Parkinson's disease. Int J Mol Sci. 2019;20(3):719.

38. Madav Y, Wairkar S, Prabhakar B. Recent therapeutic strategies targeting beta amyloid and tauopathies in Alzheimer's disease. Brain Res Bull. 2019; 146:171-84.

39. laccarino L, Tammewar G, Ayakta N, Baker SL, Bejanin A, Boxer AL, GornoTempini ML, Janabi M, Kramer JH, Lazaris A, et al. Local and distant relationships between amyloid, tau and neurodegeneration in Alzheimer's disease. Neuroimage Clin. 2018;17:452-64.

40. Tripathi T, Kalita P. Synergistic effect of amyloid-beta and tau disrupts neural circuits. ACS Chem Neurosci. 2019;10:1129-30.

41. Davtyan H, Ghochikyan A, Petrushina I, Hovakimyan A, Davtyan A, Cribbs DH, Agadjanyan MG. The MultiTEP platform-based Alzheimer's disease epitope vaccine activates a broad repertoire of $T$ helper cells in nonhuman primates. Alzheimers Dement. 2014;10:271-83.

42. Davtyan H, Zagorski K, Petrushina I, Kazarian K, Goldberg NRS, Petrosyan J, Blurton-Jones M, Masliah E, Cribbs DH, Agadjanyan MG, Ghochikyan A. MultiTEP 
platform-based DNA vaccines for alpha-synucleinopathies: preclinical evaluation of immunogenicity and therapeutic potency. Neurobiol Aging. 2017:59:156-70.

43. Fulop T, Larbi A, Dupuis G, Le Page A, Frost EH, Cohen AA, Witkowski JM, Franceschi C. Immunosenescence and Inflamm-aging as two sides of the same coin: friends or foes? Front Immunol. 2017;8:1960.

44. Petrushina I, Davtyan H, Hovakimyan A, Davtyan A, Passos GF, Cribbs DH, Ghochikyan A, Agadjanyan MG. Comparison of efficacy of preventive and therapeutic vaccines targeting the $\mathrm{N}$ terminus of beta-amyloid in an animal model of Alzheimer's disease. Mol Ther. 2017;25:153-64.

45. Frenkel D, Balass M, Solomon B. N-terminal EFRH sequence of Alzheimer's beta-amyloid peptide represents the epitope of its anti-aggregating antibodies. J Neuroimmunol. 1998;88:85-90.

46. Agadjanyan $\mathrm{MG}$, Petrovsky N, Ghochikyan A. A fresh perspective from immunologists and vaccine researchers: active vaccination strategies to prevent and reverse Alzheimer's disease. Alzheimers Dement. 2015;11:1246-59.

47. Wiessner C, Wiederhold KH, Tissot AC, Frey P, Danner S, Jacobson LH, Jennings GT, Luond R, Ortmann R, Reichwald J, et al. The secondgeneration active Abeta immunotherapy CAD106 reduces amyloid accumulation in APP transgenic mice while minimizing potential side effects. J Neurosci. 2011;31:9323-31.

48. Vandenberghea R, Rivierec ME, Caputoc A, Sovagod J, Maguiree RP, Farlow M, Marottag G, Sanchez-Valleh R, Scheltensi P, Ryan JM, Graf A. Active Ab immunotherapy CAD106 in Alzheimer's disease: a phase 2b study. Alzheimer's Dementia. 2017;3:10-22.

49. Wang CY, Wang PN, Chiu MJ, Finstad CL, Lin F, Lynn S, Tai YH, De Fang X, Zhao K, Hung CH, et al. UB-311, a novel UBITh((R)) amyloid beta peptide vaccine for mild Alzheimer's disease. Alzheimers Dement (N Y). 2017;3:262-72.

50. Rinne JO, Brooks DJ, Rossor MN, Fox NC, Bullock R, Klunk WE, Mathis CA, Blennow K, Barakos J, Okello AA, et al. 11C-PiB PET assessment of change in fibrillar amyloid-beta load in patients with Alzheimer's disease treated with bapineuzumab: a phase 2, double-blind, placebo-controlled, ascending-dose study. Lancet Neurol. 2010;9:363-72.

51. Panza F, Frisardi V, Imbimbo BP, D'Onofrio G, Pietrarossa G, Seripa D, Pilotto A, Solfrizzi V. Bapineuzumab: anti-beta-amyloid monoclonal antibodies for the treatment of Alzheimer's disease. Immunotherapy. 2010;2:767-82.

52. Sakakibara Y, Sekiya M, Saito T, Saido TC, lijima KM. Cognitive and emotional alterations in App knock-in mouse models of Abeta amyloidosis. BMC Neurosci. 2018;19:46.

53. Webster SJ, Bachstetter AD, Van Eldik LJ. Comprehensive behavioral characterization of an APP/PS-1 double knock-in mouse model of Alzheimer's disease. Alzheimers Res Ther. 2013;5:28.

54. Saito T, Matsuba Y, Mihira N, Takano J, Nilsson P, Itohara S, Iwata N, Saido TC. Single App knock-in mouse models of Alzheimer's disease. Nat Neurosci. 2014;17:661-3.

55. Masuda A, Kobayashi Y, Kogo N, Saito T, Saido TC, Itohara S. Cognitive deficits in single App knock-in mouse models. Neurobiol Learn Mem. 2016;135:73-82.

56. Saito T, Mihira N, Matsuba Y, Sasaguri H, Hashimoto S, Narasimhan S, Zhang B, Murayama S, Higuchi M, Lee VMY, et al. Humanization of the entire murine Mapt gene provides a murine model of pathological human tau propagation. J Biol Chem. 2019;294:12754-65.

57. Sasaguri H, Nilsson P, Hashimoto S, Nagata K, Saito T, De Strooper B, Hardy J, Vassar R, Winblad B, Saido TC. APP mouse models for Alzheimer's disease preclinical studies. EMBO J. 2017;36:2473-87.

58. Gordon DL, Sajkov D, Woodman RJ, Honda-Okubo Y, Cox MM, Heinzel S, Petrovsky N. Randomized clinical trial of immunogenicity and safety of a recombinant $\mathrm{H} 1 \mathrm{N1} / 2009$ pandemic influenza vaccine containing Advax polysaccharide adjuvant. Vaccine. 2012;30:5407-16.

59. Gordon D, Kelley P, Heinzel S, Cooper P, Petrovsky N. Immunogenicity and safety of Advax, a novel polysaccharide adjuvant based on delta inulin, when formulated with hepatitis B surface antigen: a randomized controlled phase 1 study. Vaccine. 2014;32:6469-77.

60. Heddle R, Russo P, Petrovsky N, Hanna R, Smith A. Immunotherapy - 2076. A controlled study of delta inulin-adjuvanted honey bee venom immunotherapy. World Allergy Organ J. 2013;6:P158.

61. Petrovsky N, Cooper PD. Advax, a novel microcrystalline polysaccharide particle engineered from delta inulin, provides robust adjuvant potency together with tolerability and safety. Vaccine. 2015;33(44):5920-6.

\section{Publisher's Note}

Springer Nature remains neutral with regard to jurisdictional claims in published maps and institutional affiliations.

Ready to submit your research? Choose BMC and benefit from:

- fast, convenient online submission

- thorough peer review by experienced researchers in your field

- rapid publication on acceptance

- support for research data, including large and complex data types

- gold Open Access which fosters wider collaboration and increased citations

- maximum visibility for your research: over $100 \mathrm{M}$ website views per year

At BMC, research is always in progress.

Learn more biomedcentral.com/submissions 